\title{
Technological, Sensorial and Nutritional Meat Quality Traits from Pig Fed with Conventional and Unconventional Diets
}

\author{
Carine C. Hedji, Frédéric M. Houndonougbo, Ulbad P. Tougan, Marcel R. B. Houinato, \\ Didier E. Fiogbe \\ Département de Zoologie, Faculté des Sciences et Techniques, Laboratoire de Recherche sur les Zones \\ Humides (LRZH), Abomey-Calavi, Bénin \\ Email: christmel13@yahoo.fr
}

Received 19 September 2015; accepted 11 December 2015; published 14 December 2015

Copyright (C) 2015 by authors and Scientific Research Publishing Inc.

This work is licensed under the Creative Commons Attribution International License (CC BY). http://creativecommons.org/licenses/by/4.0/

(c) (i) Open Access

\section{Abstract}

The aim of the study was to evaluate the impact of unconventional food resources on the quality of pig meat. 90 pigs of which 20 were slaughtered at 180 days old for meat quality evaluation. It came out from the study that the highest $L^{*}$ and $b^{*}$ were obtained in $A 0$ commercial feed, while the highest a* was recorded in A3 $(P<0.05)$. From 45 minutes to 24 h post-mortem, the highest pork hue value was recorded in A2, whereas the highest chromaticity was found in $\mathrm{A0}$. The $\mathrm{pH} 45$ and pH 24 of Mld (Muscle Longissimus dorsi) were lower in control group than in experimental groups. The cooking loss and water-holding capacity of the meat from A4 were higher than those of other treatments. Luminance, redness, yellowness, chroma values and $\mathrm{pH}$ of the pork had increased during the post-mortem aging time for the both diet treatments while the hue value decreased $(\mathrm{P}<$ 0.05). Nutritionally, the protein content, the fat content, the dry matter content and the ash content varied respectively from $24.45 \%$ to $26.87 \%, 0.52 \%$ to $1.6 \%, 26 \%$ to $27.5 \%$ and $1.1 \%$ to $1.79 \%$ with the highest protein contents found in meat from unconventional feed $\mathrm{A4}(\mathrm{P}<0.01)$ while the highest fat content $(1.6 \%)$ was obtained from meat of the control group $A 0(P<0.001)$. The texture of the meat from the control group was better than those of experimental groups $(P<0.01)$. Overall, unconventional diet based on Azolla and Moringa improves technological and nutritional pork quality.

\section{Keywords}

Pig, Meat Quality, Unconventional Diet, Benin

How to cite this paper: Hedji, C.C., Houndonougbo, F.M., Tougan, U.P., Houinato, M.R.B. and Fiogbe, D.E. (2015) Technological, Sensorial and Nutritional Meat Quality Traits from Pig Fed with Conventional and Unconventional Diets. Food and Nutrition Sciences, 6, 1514-1521. http://dx.doi.org/10.4236/fns.2015.616156 


\section{Introduction}

Meat is an important foodstuff and one of the most expensive components of human nutrition [1]. Meat provides valuable amounts of protein, fatty acids, vitamin, minerals and other bioactive compounds. Indeed, a variety of meat is eaten in order to get balanced diets and more appetite. According to the three important aspects such as nutrition sensorial and beliefs that are required to be improved [2], people can prefer chicken, beef and pork. The meat derived from hunting is appreciable by others, although consumers are highly interested in the quality of the products they eat, especially when this refers to meat [3]. FAO (2014) [4] claimed that pig meat consumption had severely increased and at the same time established a growth of consumer preferences to satisfy the tastes of the refined meat and to ensure a healthy and balanced nutrition due to its good quality. This has desirable implications on enterprise profit as feed constitutes a large portion (60\% - 70\%) of pig enterprise costs [5], [6]. Thus, pig presents some characteristics that are positive for profitability: high growth rate and interesting food conversion ratio [7]. The value of a meat animal is realised when its product is marketed and expressed relative to the input costs incurred [8]. According to Lee et al. [9], the surface exudate expressed as water holding capacity or drip loss, the ultimate $\mathrm{pH}(\mathrm{pH} 24)$ and the colour are the three important parameters to find out more about the quality of pork. By this predictors, meat can be classified into quality categories such as PSE (pale. soft. exudative), normal or RFN (red. firm. non-exudative) and DFD (dark, firm, and dry) meat. Beside these traditional categories, Tomovic let al. [10] have also reported RSE (reddish-pink. soft. exudative) and PFN (pale, firm and non-exudative) defects in pork. The aim of this work is to compare the meat quality from conventional and unconventional commercial feeds in pig.

\section{Materials and Methods}

\subsection{Area of Study}

The study was conducted at the experimental farm of the Agronomic Science Faculty of the University of Abomey-Calavi located in Abomey-Calavi in Atlantic Department. Situated at latitude of $6^{\circ} 27^{\prime}$ North and at a longitude of $2^{\circ} 21^{\prime}$ East, the Commune of Abomey-Calavi covers an area of $650 \mathrm{~km}^{2}$ with a population of 307,745 inhabitants [11]. This area exhibits climatic conditions of sub-equatorial type, characterized by two rainy seasons with an uneven spatial and temporal distribution of rainfall: major (from April to July) and minor (from September to November). These two seasons are separated by a dry season. Average rainfall is close to $1200 \mathrm{~mm}$ per year. The monthly average temperatures vary between $27^{\circ} \mathrm{C}$ and $31^{\circ} \mathrm{C}$ and the relative air humidity fluctuates between $65 \%$, from January to March, and 97\%, from June to July.

\subsection{Methodology}

\subsubsection{Animal}

A total of 90 pigs were divided in 5 groups constituted and used for the study. The first group was fed with a conventional commercial feed (A0). The four following groups were respectively fed with four different unconventional feeds (A1, A2, A3 and A4) containing Azolla, Moringa, rice bran, and different rates of chicken and fish viscera (Table 1).

The pigs were fed with wet diets. After the study completion at 90 days, four pigs from each group were selected for the evaluation meat quality. The traits of meat quality were examined in Longissimus dorsi.

\subsubsection{Technological Quality}

The $\mathrm{pH}$ was recorded at 45 minutes and 24 hours post mortem using a portable pH-meter HANNA. Drip loss was determined by the method used by Tougan et al. [12] after cooling for $24 \mathrm{~h}$ at $4^{\circ} \mathrm{C}$. Cooking loss was determined by placing weight samples of $L$. dorsi in polythene bags and heating then in a water bath at $70^{\circ} \mathrm{C}$ for 50 min. The samples were then weighed and cooking loss was calculated as a percentage of weight of the original samples.

The colour of the meat was measured a slaughtering day and 24 hours post mortem with a Minolta Chromameter CR400 (Minolta Corporation, Ramsey, NJ, USA) after exposing the surface to the air for $1 \mathrm{H} 30 \mathrm{~min}$ at $4^{\circ} \mathrm{C}$. The average of triplicate measurements was recorded and the results were expressed as C.I.E (Commission Internationale de l'Eclairage) $\mathrm{L}^{*}, \mathrm{a}^{*}$ and $\mathrm{b}^{*}$. The parameters $\mathrm{L}^{*}, \mathrm{a}^{*}$ and $\mathrm{b}^{*}$ represent lightness, redness and yellowness. From the $\mathrm{a}^{*}$ and $\mathrm{b}^{*}$ values, the hue $(\mathrm{Hab})$ and the chroma $(\mathrm{Cab})$ values were calculated. Hue, namely 
Table 1. Composition of the different diets.

\begin{tabular}{|c|c|c|c|c|c|}
\hline & Control diet & & & 1 diets & \\
\hline Foodstuffs (\%) & $\mathrm{A} 0$ & A1 & A2 & A3 & A4 \\
\hline Maize & 29 & - & - & - & - \\
\hline Wheat bran & 24.65 & - & - & - & - \\
\hline Palm kernel cake & 32.5 & - & - & - & - \\
\hline Cotton seed cake & 5 & - & - & - & - \\
\hline Fish meal & 5 & - & - & - & - \\
\hline Shell & 1.5 & - & - & - & - \\
\hline C5 & 1.5 & - & - & - & - \\
\hline Phosphate & 0.5 & - & - & - & - \\
\hline Sulfate & 0.05 & - & - & - & - \\
\hline Salt & 0.3 & - & - & - & - \\
\hline Azolla meal & - & 40 & 40 & 40 & 40 \\
\hline Moringa meal & - & 25 & 25 & 25 & 25 \\
\hline Rice bran & - & 30 & 30 & 30 & 30 \\
\hline Chicken viscera & - & 0 & 1.5 & 3.5 & 5 \\
\hline Fish viscera & - & 5 & 3.5 & 1.5 & 0 \\
\hline Total & 100 & 100 & 100 & 100 & 100 \\
\hline
\end{tabular}

the observable colour (e.g. red, blue, yellow), is an angular measurement calculated by the following equation: $\mathrm{Hab}=\tan ^{-1}\left(\mathrm{~b}^{*} / \mathrm{a}^{*}\right)$ [13]. Chroma is an expression of saturation or intensity of the colour attained and is expressed by the equation: $\mathrm{Cab}=(\mathrm{a} \times 2+\mathrm{b} \times 2) 1 / 2$ [13].

\subsubsection{Sensory Quality}

Sensory analysis was performed on each dietary treatment with a panel of jury members from 12 randomly selected potential consumers. For the tasting, two groups of identical samples of $50 \mathrm{~g}$ of Longissimus dorsi muscle cuts were used. These pieces were boiled with water in a pot without seasoning and salt for 1 hour at $75^{\circ} \mathrm{C}$. After cooling to room temperature, the samples of cooked meat were cut into small identical cubes. Each judge received in a different colour trim a portion of each cutting counterpart belonging to each dietary treatment and completed a form of summary of the results of the tasting. Three repetitions were made for each cut dietary treatment. The judges evaluated the three important sensory characteristics of meat (tenderness, juiciness and flavour). These characteristics were rated on scales of 1 to 5 . For tenderness, the scores 1, 2, 3, 4, and 5 correspond respectively to very hard, hard, acceptable, tender and very tender. As for juiciness, the scores 1, 2, 3, 4, and 5 correspond respectively very dry, dry, acceptable, soft and very soft. The intensity of flavour can obtain the score very low (1), low (2), acceptable (3), strong (4) and very strong (5).

\subsubsection{Chemical Composition}

The chemical composition was determined according to the standards used by Tougan et al. [14]. Moisture content was determined gravimetrically by drying $6 \mathrm{~g}$ of meat at $105^{\circ} \mathrm{C}$ accordingly to the NF V $04-401$ French standards method. Each value was an average of 2 measurements. Crude protein was determined by Kjeldahl method according to the NF V 04 - 407 norm and using a Kjeltec Auto Sampler System 1035 Analyzer (Foss, Benelux). Each analysis was repeated twice. The total ash content was determined according to the NF V 04 404 French standard method. About $6 \mathrm{~g}$ of samples were ashed in an oven maintained at $550^{\circ} \mathrm{C}$ to determine ash content and was repeated twice. The fat content was determined by Soxhlet method according to the NF V 04 402 standard ISO 1443:1973. Each analysis was repeated twice using petroleum ether at $40^{\circ} \mathrm{C}-60^{\circ} \mathrm{C}$. 


\subsection{Statistical Analysis}

The data collected on the meat quality traits of the different group were analysed with the software SAS (Statistical Analysis System, 2006). For the analysis of variance, a fixed effects linear model was adjusted to the data and includes the fixed effects of the diet and post mortem aging time. The F test was used to determine the significance level of each effect in the model. Means were compared two by two by the Student's t test.

\section{Results}

\subsection{Technological Quality of Meat}

The variation of technological quality of meat according to the diet and the post mortem (PM) aging time are given in Table 2. The highest luminance and yellow index were obtained in A0 commercial feed, while the highest redness was recorded in the treatment A3 $(\mathrm{P}<0.05)$. From 45 minutes PM to $24 \mathrm{~h}$ post-mortem the hue was raised at the feed A2, whereas a higher chromaticity was noticed with the feed A0.

The $\mathrm{pH}$ values ranged from 5.54 to 5.38 for the control feed A0 but varied from 5.7 to 6.64 for the meat obtained from unconventional feeds. During the experiment, $\mathrm{pH} 45$ (recorded at 45 minutes PM) and pH 24 (recorded at 24 hours PM) in the muscle Longissimus dorsi were lower in control group than in experimental groups. The $\mathrm{pH}$ values were significantly different among all of the five treatments $(\mathrm{P}<0.05)$. The $\mathrm{pH}$ drop was rapid in the group fed with unconventional feeds.

The cooking loss and water-holding capacity of the meat from the treatment A4 were higher than those of other treatments. The loss of juices during cooking and water holding capacity were significantly different $(\mathrm{P}<$ $0.05)$, whereas no difference was observed for the drip loss $(\mathrm{P}>0.05)$. The highest value of cooking loss (24.24\%) was observed in meat from unconventional feed A3, while the higher drip loss (3.05\%) was recorded in meat from the feed A4. Water holding capacity was of 22.85 for unconventional feeds to $20.5 \%$ for the control feed A0.

Luminance, redness, yellowness, chroma values and $\mathrm{pH}$ of the pork had increased during the post-mortem aging time (from 45 minutes to 24 hours) for the both diet treatments while the hue value decreased $(\mathrm{P}<0.05)$.

Table 2. Effect of diet (A0, A1, A2, A3 and A4) and post-mortem aging time on pork technological quality.

\begin{tabular}{|c|c|c|c|c|c|c|c|c|c|c|c|c|c|}
\hline \multirow{2}{*}{ Variables } & \multirow{2}{*}{ Day } & \multicolumn{2}{|c|}{ A0 } & \multicolumn{2}{|c|}{ A1 } & \multicolumn{2}{|c|}{ A2 } & \multicolumn{2}{|c|}{ A3 } & \multicolumn{2}{|c|}{ A4 } & \multirow{2}{*}{$\begin{array}{l}\text { Diet } \\
\text { effect }\end{array}$} & \multirow{2}{*}{$\begin{array}{l}\text { Effect of PM } \\
\text { aging time }\end{array}$} \\
\hline & & Mean & ES & Mean & ES & Mean & ES & Mean & ES & Mean & ES & & \\
\hline \multirow{2}{*}{$\mathbf{L}^{*}$} & J0 & 51.5 & 4 & 50.1 & 3.5 & 48.9 & 3.5 & 48.6 & 3.5 & 48.6 & 3.6 & NS & \multirow{2}{*}{ NS } \\
\hline & $\mathrm{J} 1$ & 52.7 & 2.6 & 52.2 & 2.4 & 52.7 & 5.3 & 52.3 & 2.4 & 51.5 & 3.3 & NS & \\
\hline \multirow{2}{*}{$\mathbf{a}^{*}$} & J0 & 9.5 & 2.3 & 8.7 & 3.4 & 7 & 2.5 & 9.8 & 2.2 & 8.2 & 2.2 & $* * *$ & \multirow{2}{*}{ * } \\
\hline & $\mathrm{J} 1$ & 11.3 & 2 & 9.7 & 2.5 & 8.8 & 1.8 & 11.5 & 2.5 & 10.8 & 2.1 & $* * *$ & \\
\hline \multirow{2}{*}{$\mathbf{b}^{*}$} & J0 & 8.6 & 3.2 & 6.5 & 2.5 & 6 & 1.7 & 7.9 & 2.5 & 6.7 & 1.9 & $* * *$ & \multirow{2}{*}{ * } \\
\hline & $\mathrm{J} 1$ & 11.5 & 1.4 & 9.6 & 2 & 10.2 & 1.7 & 11.1 & 2.2 & 10.8 & 2 & $* * *$ & \\
\hline \multirow{2}{*}{ Hue H* } & J0 & 0.2 & 0.03 & 0.17 & 0.04 & 0.21 & 0.05 & 0.15 & 0.03 & 0.18 & 0.03 & $* * *$ & \multirow{2}{*}{ * } \\
\hline & $\mathrm{J} 1$ & 0.2 & 0.02 & 0.16 & 0.04 & 0.17 & 0.04 & 0.14 & 0.03 & 0.14 & 0.02 & $* * *$ & \\
\hline \multirow{2}{*}{ Chroma C* } & J0 & 12.9 & 3.6 & 10.9 & 4.02 & 9.3 & 2.8 & 12.6 & 3.1 & 10.7 & 2.6 & $* * *$ & \multirow{2}{*}{ * } \\
\hline & $\mathrm{J} 1$ & 16.1 & 2.2 & 13.7 & 3 & 13.5 & 2.3 & 16 & 3. & 15.4 & 2.7 & $* * *$ & \\
\hline \multirow{2}{*}{ pH } & J0 & 5.5 & 0.5 & 6.6 & 0.5 & 5.8 & 0.6 & 6.7 & 0.3 & 6.5 & 0.4 & $* * *$ & \multirow{2}{*}{ * } \\
\hline & $\mathrm{J} 1$ & 5.4 & 0.2 & 5.9 & 0.2 & 5.6 & 0.3 & 5.7 & 0.24 & 5.6 & 0.3 & $* * *$ & \\
\hline Cooking loss & & 18.5 & 5.4 & 18 & 2.8 & 19.7 & 7.6 & 24.2 & 3.4 & 19.8 & 6 & $* * *$ & $*$ \\
\hline Drip loss & & 2 & 0.8 & 2.2 & 1.3 & 2.3 & 1.9 & 2.2 & 1.2 & 3.05 & 1.5 & NS & * \\
\hline WHC & & 20.5 & 3.2 & 20.1 & 3.2 & 22.03 & 3.2 & 26.5 & 3.2 & 22.8 & 3.2 & $* * *$ & * \\
\hline
\end{tabular}

WHC: Water-holding capacity. SE: Standard error. 


\subsection{Nutritional and Sensorial Quality of Meat}

Nutritionally, the protein content, the fat content, the dry matter content and the ash content varied respectively from $24.45 \%$ to $26.87 \%, 0.52 \%$ to $1.6 \%$, $26 \%$ to $27.5 \%$ and $1.1 \%$ to $1.79 \%$ (Table 3 ).

The highest protein contents were found in meat from unconventional feed A4 $(\mathrm{P}<0.01)$ while the highest fat content $(1.6 \%)$ was obtained from meat of the control group A0 $(\mathrm{P}<0.001)$. Ash content was more important in meat from the unconventional fed A4 $(\mathrm{P}<0.01)$. However, the meat the control group contained more dry matter than those of the experimental groups $(\mathrm{P}<0.01)$.

For the sensory quality of the meat, no difference was found between flavor and juiciness of meat from control and experimental groups $(\mathrm{P}>0.05)$. However, the texture of the meat from the control group was higher than those of the meat from experimental groups $(\mathrm{P}<0.01)$ (Table 4).

\section{Discussion}

\subsection{Variation of Meat Technological Quality}

There are many factors which affect the quality of pig meat such as genetics associated factors, nutrition, rearing conditions, handling of animals during loading into vehicles, transportation, depot, stunning, slaughtering and cooling of the carcass [15]. The results found herein indicate that there are many differences in post mortem metabolic rate and meat quality according to the post mortem aging time and diets. In the current study, the ultimate $\mathrm{pH}$ of meat is related to several meat quality aspects including $\mathrm{L}^{*}$ value and water losses. In agreement with no treatment effects on the $\mathrm{pH}$ of meat, no significant effects of treatment were observed on $\mathrm{L}^{*}$ value or on drip and cooking losses in the current study. The redness $\left(\mathrm{a}^{*}\right)$ of meat is greatly influenced by the meat concentration in pigment [16] and by the $\mathrm{pH}$ of the meat because oxidation and reduction processes of myoglobin are $\mathrm{pH}$-dependent [17]. According to the current results, the $\mathrm{pH}$ value recorded at 45 minutes post-mortem in Mld was lower in control group. It was found that meat of pigs was influenced by the feed quality. These results confirm the finding of De Smet et al. [18] who indicate that meat quality depends highly on the diets.

High fibre in unconventional diets may inhibit the availability of iron which can limit pigment formation [17]. Water-holding capacity is an important technological parameter of meat quality. It was different among investigated pig group in our study. According to Hocquette et al. (2005) [19], the water holding capacity influences juiciness of the meat. In the current study, the water holding capacity is higher in pigs fed unconventional diet with relatively higher juiciness. According to Clinquart et al. [20], meat with good water holding capacity helps

Table 3. Effect of diet (A0, A1, A2, A3 and A4) on the nutritional value of pork.

\begin{tabular}{cccccccc}
\hline Attributes & A0 & A1 & A2 & A3 & A4 & RSD & ANOVA \\
\hline Protein (g/100 g) & $24.5 \mathrm{a}$ & $24.5 \mathrm{a}$ & $25.2 \mathrm{~b}$ & $25.9 \mathrm{c}$ & $26.8 \mathrm{~d}$ & 0.7 & $* *$ \\
Fat (g/100 g) & $1.6 \mathrm{a}$ & $0.5 \mathrm{~b}$ & $0.5 \mathrm{~b}$ & $0.7 \mathrm{c}$ & $1 \mathrm{~d}$ & 0.5 & $* * *$ \\
Dry matter (g/100 g) & $27.5 \mathrm{a}$ & $27.3 \mathrm{a}$ & $26 \mathrm{~b}$ & $27.4 \mathrm{a}$ & $27.3 \mathrm{a}$ & 0.8 & $* *$ \\
Ash (g/100 g) & $1 \mathrm{a}$ & $1.3 \mathrm{~b}$ & $1.5 \mathrm{c}$ & $1.6 \mathrm{~cd}$ & $1.8 \mathrm{~d}$ & 0.4 & $* *$ \\
\hline
\end{tabular}

$* *: \mathrm{P}<0.01 ; * * *: \mathrm{P}<0.001$. The means of the same line followed by different letters differ significantly with the threshold of 5\%. RSD: Residual standard deviation.

Table 4. Effect of diet (A0, A1, A2, A3 and A4) on pork sensory quality.

\begin{tabular}{|c|c|c|c|c|c|c|c|c|c|c|c|}
\hline \multirow{2}{*}{ Variables } & \multicolumn{2}{|c|}{ A0 } & \multicolumn{2}{|c|}{ A1 } & \multicolumn{2}{|c|}{ A2 } & \multicolumn{2}{|c|}{ A3 } & \multicolumn{2}{|c|}{ A4 } & \multirow{2}{*}{ ANOVA } \\
\hline & Mean & ES & Mean & ES & Mean & ES & Mean & ES & Mean & ES & \\
\hline Flavour & 2.7 & 0.8 & 2.2 & 1.1 & 2.3 & 0.7 & 2.5 & 1.3 & 2.5 & 1.08 & NS \\
\hline Juiciness & 2.8 & 0.7 & 2.6 & 0.9 & 2.9 & 0.9 & 3.1 & 0.8 & 3.1 & 0.8 & NS \\
\hline Texture & 2.5 & 0.9 & $1.3 \mathrm{~b}$ & 0.5 & 2.1 & 0.8 & $3.1 \mathrm{a}$ & 1.08 & $3.1 \mathrm{a}$ & 0.8 & * \\
\hline
\end{tabular}

*: P < 0.05; NS: Non-significant. The means of the same line followed by different letters differ significantly with the threshold of $5 \%$. 
to limit weight losses during its conservation and its transformation into cooked products. Therefore, it could be concluded that the unconventional feeds used in the current study improve technological properties in pig meat of Benin. The values of WHC found herein are below those found by Jukna and Jukna [21] and twice higher than the value reported by Kusec et al. [22] on the Pietrain and Large White pigs. The conditions of slaughter and post-slaughter being identical in this study, the water retention capacity differences may be related to the feed composition and its impact on muscle characteristics.

\subsection{Variation of Meat Nutritional Quality}

The nutritional value of pork found herein is better compared to the value reported by Rybarczyk et al. [23] on the Pietrain pig meat quality and other crossbred pigs with Pietrain. Similarly, the meat protein content recorded in the current study is higher than the results of Jukna and Jukna [21] and Rybarczyk et al. [23].

The protein and fat contents of pork derived from unconventional feed used in this study are better than those of pigs fed with the conventional diet. In addition the technological quality of the meat was not affected by the type of the diet. Therefore, it is possible to get good quality of pork by feeding the animals with unconventional local resources.

Research carried out in recent years emphasized that for consumers the sensory quality of culinary meat, which is determined mainly by level of intramuscular fat and other traits such as drip loss and the pH of the meat, is very important. The $\mathrm{pH}$ has a high influence on water holding capacity (WHC), which is closely related to product yield and pork quality [20]. WHC is the ability of meat to retain its water during processing, storage and cooking. Low WHC often results in high drip loss and poor eating quality (dryer and tougher in the cooked state). Water loss means a loss of saleable product yield. The values of $\mathrm{pH}$, drip loss, cooking loss, colour ( $\mathrm{L}^{*}$, $\mathrm{a}^{*}, \mathrm{~b}^{*}$ ) are within the values reported in literature [24]-[26].

The level of intramuscular fat depends on breed, portion of meat in the carcass, slaughter weight and nutrition of the animal during the growing period [27]. Recent studies highlighted the link between these properties and the level of intramuscular fat in meat and marbling. These two traits vary according to breed and environmental conditions. Fat content in muscle tissue influences meat quality significantly, particularly tenderness, juiciness and flavour of meat, and drip loss. Recent studies on crosses between Naïma sows and boars suggested the existence of an intramuscular fat gene in animals where high levels and a high degree of variability of intramuscular fat were observed [28] [29].

Concerning the implications of the feeding regime for pork quality traits, the results conclusively confirmed the results of Sundrum et al. [30], during their study on the effects of feeding strategies, genotypes, sex, and birth weight on carcass and meat quality traits under organic pig production conditions. They found that lean meat percentage and meat area of the muscle Longissimus dorsi (Mld) and the meat: fat ratio were markedly lower with feeding regime growing and finishing phase than with the regimes finishing and control diet (p < 0.05), whereas the fat area was not affected. Due to the large variation in drip losses after 24 h, differences between feeding regimes were not statistically significant ( $p>0.05)$. In contrast, intramuscular fat content of the Mld in their study clearly increased with feeding regime growing and finishing compared with the control diet from $1.22 \%$ to $2.80 \%$ (p < 0.05$)$.

In studies of Essén-Gustavsson [31], muscle fibre composition and the oxidative and glycolytic capacity did not differ between the pigs given a low- and a high-protein diet whereas the low-protein diet caused a higher intramuscular fat content than the pigs fed a high-protein diet. Intramuscular fat values correlated with triglyceride content in the muscle, which in turn was negatively related to mean fibre area. Larzul et al. [32] did not find any relationship between intramuscular fat content and the numerical percentage of fibre types at a commercial slaughter weight of purebred Large White pigs.

The protein contents of pork found herein are higher than those obtained by Sundrum et al. [30], while the intramuscular fat contents recorded in our study are lower than the values reported by Sundrum et al. [30] in four different genotypes: Pietrain $\times$ (German Landrace $\times$ Large White), Duroc crossed with a strain of German Landrace, Pietrain $\times$ German Swabian Hall, and purebred German Swabian Hall breed.

\section{Conclusion}

Analysing the pig meat from unconventional and conventional feed, it can be concluded that unconventional meat is healthier with higher protein content and lower fat content. The feeding regime was the main source of 
variation for intramuscular fat content in the Longissimus dorsi muscle. Unconventional diet based on Azolla and Moringa can improve technological and nutritional pork quality.

\section{Acknowledgements}

The authors thank the "University of Abomey-Calavi" for their financial contribution and the Laboratory of Animal Biotechnology and Meat Technology of Polytechnic School of Abomey-Calavi for the technical supports.

\section{References}

[1] Šubrt, J. and Mikšik, J. (2002) A Comparison of Selected Quality Parameters of the Meat of Czech Pied and Montbéliard Bulls. Czech Journal of Animal Science, 47, 57-63.

[2] Connor, W.E. (2000) Importance of n-3 Fatty Acids in Health and Disease. The American Journal of Clinical Nutrition, 71, 171-175.

[3] Guerrero, A., Velandia Valero, M., Campo, M.M. and Sañudo, C. (2013) Some Factors that Affect Ruminant Meat Quality: From the Farm to the Fork. Review. Acta Scientiarum Animal Sciences, 35, 335-347.

[4] FAO (2014) World Meat Markets at a Glance. 15 p.

[5] Meffeja, F., Dongmo, T. and Fotso, J.-M. (2006) Teneur énergétique de la ration et performances de croissance du porc au Cameroun. Cahiers Agricultures, 15, 301-305.

[6] Hoque, M.A., Kadowak, H., Shibata, T. Oikawa, T. and Suzuki, K. (2007) Genetic Parameters for Measures of Residual Feed Intake and Growth Traits in Seven Generations of Duroc Pigs. Journal of Animal Breeding and Genetics, 124, 108-116. http://dx.doi.org/10.1111/j.1439-0388.2007.00650.x

[7] McPhee, C.P. and MacBeth, M. (2000) A Profit Model for Estimating Economic Values of Traits in the National Pig Improvement Program. PDRC DAG58/1339 Final Report.

[8] Dube, B., Mulugeta, S.D., van der Westhuizen, R.R. and Dzama, K. (2011) Non-Genetic Factors Affecting Growth Performance and Carcass Characteristics of Two South African Pig Breeds. South African Journal of Animal Science, 41. http://dx.doi.org/10.4314/sajas.v41i2.71021

[9] Lee, S., Norman, J.M., Gunasekaran, S., van Laack, R.L.J.M., Kim, B.C. and Kaufmann, R.G. (2000) Use of Electrical Conductivity to Predict Water Holding Capacity in Post-Rigor Pork. Meat Science, 55, 385-389. http://dx.doi.org/10.1016/S0309-1740(99)00166-7

[10] Tomovic, V.M., Zlender, B.A., Jokanovic, M.R., Tomovic, M.S., Sojic, B.V., Skaljac, S.B., Tasic, T.A., Ikonic, P.M., Soso, M.M. and Hromis, N.M. (2014) Technological Quality and Composition of the M. Semimembranosus and M. Longissimus Dorsi from Large White and Landrace Pigs. Agriculture and Food Science, 23, 9-18.

[11] INSAE (2010) Institut National de Statistique et l’Analyse Economique. Rapport annuel d'activités. Cotonou, Bénin, $360 \mathrm{p}$.

[12] Tougan, U.P., Dahouda, M., Salifou, C.F.A., Ahounou, G.S., Kpodekon, M.T., Mensah, G.A., Thewis, A. and Youssao, I.A.K. (2013) Conversion of Chicken Muscle to Meat and Factors Affecting Chicken Meat Quality: A Review. International Journal of Agronomy and Agricultural Research, 3, 1-20.

[13] Hunt, R.W.G. (1991) Measuring Color. 2nd Edition, Ellis Horwood Limited, Chichester, 313 p.

[14] Tougan, P.U., Dahouda, M., Ahounou, G.S., Salifou, C.F.A., Kpodekon, M.T., Mensah, G.A., Kossou, D.N.F., Amenou, C., Kogbeto, C.E., Thewis, A. and Youssao, I.A.K. (2013) Effect of Breeding Mode, Type of Muscle and Slaughter Age on Technological Meat Quality of Local Poultry Population of Gallus gallus Species of Benin. International Journal of Biosciences, 3, 1-17.

[15] Baltić, Ž.M., Marković, R. and Đorđević, V. (2011) Nutrition and Meat Quality. Tehnologija Mesa, 52, $154-159$.

[16] Lindahl, G., Lundström, K. and Tornberg, E. (2001) Contribution of Pigment Content. Myoglobin Forms and Internal Reflectance to the Colour of Pork Loin and Ham from Pure Breed Pigs. Meat Science, 59, 141-151. http://dx.doi.org/10.1016/S0309-1740(01)00064-X

[17] Oksbjerg, N.K., Strudsholm, G.L. and Hermansen, J.E. (2005) Meat Quality of Fully or Partly Outdoor Reared Pigs in Organic Production. Acta Agriculturae Scandinavica, Section A, 55, 106-112.

[18] De Smet, S.M., Pauwels, H., De Bie, S., Demeyer, D.I., Callewier, J. and Eeckhout, W. (1996) Effect of Halothane Genotype Breed. Feed with Drawal and Lairage on Pork Quality of Belgian Slaughter Pigs. Journal of Animal Science, 74, 1854-1863.

[19] Hocquette, J.F., Cassar-Malek, I., Listrat, A., Jurie, C., Jailler, R. and Picard, B. (2005) Evolution des recherches sur le 
muscle des bovins et la qualité sensorielle de leur viande. II. Influence des facteurs d’élevage sur les caractéristiques musculaires. Cahier d'Agriculture, 14, 365-372.

[20] Clinquart, A., Leroy, B., Dottreppe, O., Hornick, J.L., Dufrasne, I.L. and Istasse, L. (2000) Les facteurs de production qui influencent la qualité de la viande des bovins Blanc Bleu belge. In: L'élevage du Blanc Bleu Belge. Journée du Centre d'Excellence du Secteur agricole et son Management (CESAM), 26 Mai 2000. Mons. 2000, 19 p.

[21] Jukna, V. and Jukna, C. (2005) The Comparable Estimation of Meat Quality of Pig Breeds and Their Combinations in Lithuania. Biotechnology in Animal Husbandry, 21, P175-P179. http://dx.doi.org/10.2298/BAH0506175J

[22] Kusec, G., Kralik, G., Petrièevie, A., Gutzmirtl, H. and Grguric, D. (2003) Meat Quality Indicators and Their Correlation in Two Crosses of Pigs. Agriculturae Conspectus Scientificus, 68, 115-119.

[23] Rybarczyk, A., Pietruszka, A., Jacyno, E. and Dvořak, J. (2011) Carcass and Meat Quality Traits of Pig Reciprocal Crosses with a Share of Pietrain Breed. Czech Journal of Animal Science, 56, 47-52.

[24] Matthews, J.O., Southern, L.L., Bidner, T.D. and Persica, M.A. (2001) Effects of Betaine, Pen Space, and Slaughter Handling Method on Growth Performance, Carcass Traits, and Pork Quality of Finishing Barrows. Journal of Animal Science, 79, 967-974.

[25] Matthews, J.O., Guzik, A.C., Lemieux, F.M., Southern, L.L. and Bidner, T.D. (2005) Effects of Chromium Propionate on Growth, Carcass Traits, and Pork Quality of Growing-Finishing Pigs. Journal of Animal Science, 83, 858-862.

[26] Czarniecka-Skubina, E., Przybylski, W., Jaworska, D., Kajak-Siemaszko, K. and Wachowicz, I. (2010) Effect of pH24 and Intramuscular Fat Content on Technological and Sensory Quality of Pork. Polish Journal of Food and Nutrition Sciences, 60, 43-49.

[27] Rosenvold, K. and Andersen, H.J. (2003) Factors of Significance for Pork Quality. A Review. Meat Science, 64, 219237. http://dx.doi.org/10.1016/S0309-1740(02)00186-9

[28] Jaworska, D., Przybylski, W., Kołoyn-Krajewska, D., Czarniecka-Skubina, E., Wachowicz, I., Trzaskowska, M., Kajak, K., Lech, A. and Niemyski, S. (2006) The Assessment of Relationships between Characteristics Determining Technological and Sensory Quality of Pork. Animal Science Papers and Reports, 24, 121-135.

[29] Przybylski, W., Kajak-Siemaszko, K., Jaworska, D., Czarniecka-Skubina, E., Wachowicz, I. and Urbańska, I. (2007) Influence of Different Level of Intramuscular Fat on Pork Quality. Animal Science, 1, 112-113.

[30] Sundruma, A., Aragona, A., Schulze-Langenhorstb, C., Bütferingb, L., Henningc, M. and Stalljohann, G. (2011) Effects of Feeding Strategies, Genotypes, Sex, and Birth Weight on Carcass and Meat Quality Traits under Organic Pig Production Conditions. NJAS—Wageningen Journal of Life Sciences, 58, 163-172. http://dx.doi.org/10.1016/j.njas.2011.09.006

[31] Essén-Gustavsson, B., Karlström, A. and Lundström, K. (1992) Muscle Fibre Characteristics and Metabolic Response at Slaughter in Pigs of Different Halothane Genotypes and Their Relation to Meat Quality. Meat Science, 31, 1-11. http://dx.doi.org/10.1016/0309-1740(92)90067-E

[32] Larzul, C., Lefaucheur, L., Ecolan, P., Gogué, J., Talmant, A., Sellier, P., Le Roy, P. and Monin, G. (1997) Phenotypic and Genetic Parameters for Longissimus Muscle Fibre Characteristics in Relation to Growth, Carcass, and Meat Quality in Large White Pigs. Journal of Animal Science, 75, 3126-3137. 